AL. 2. $2006-68$

\title{
Status of the Weidemeyer's Admiral \\ (Limenitis weidemeyerii) \\ in Alberta
}

Fish \& Whdife Division

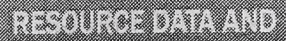

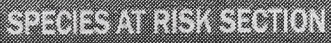

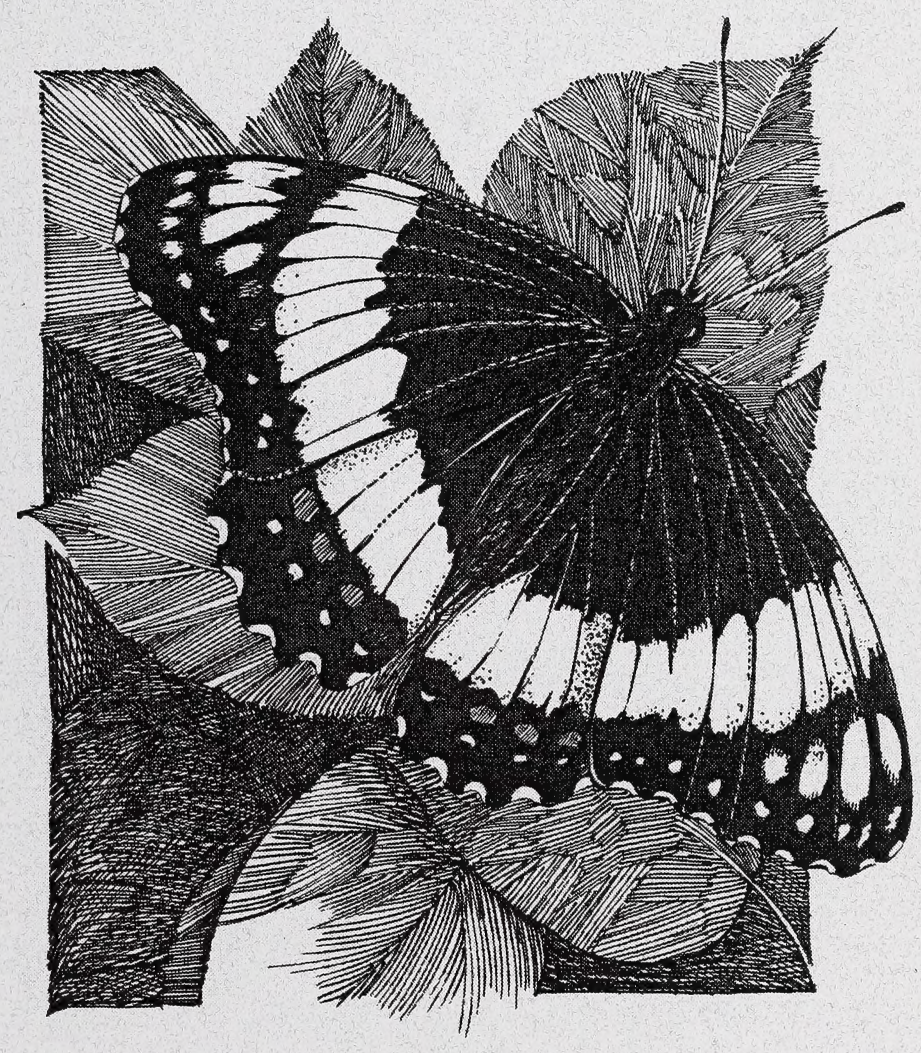

Alberta Wildlife Status Report No. 58

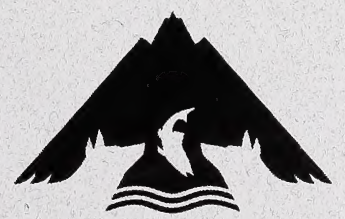

Alberta Conservation 



\title{
Status of the Weidemeyer's Admiral (Limenitis weidemeyerii) in Alberta
}

\author{
Prepared for: \\ Alberta Sustainable Resource Development (SRD) \\ Alberta Conservation Association (ACA)
}

\begin{abstract}
Prepared by:
Norbert Kondla

This report has been reviewed, revised, and edited prior to publication. It is an SRD/ACA working document that will be revised and updated periodically.
\end{abstract}

Alberta Wildlife Status Report No. 58

December 2005

Published By:
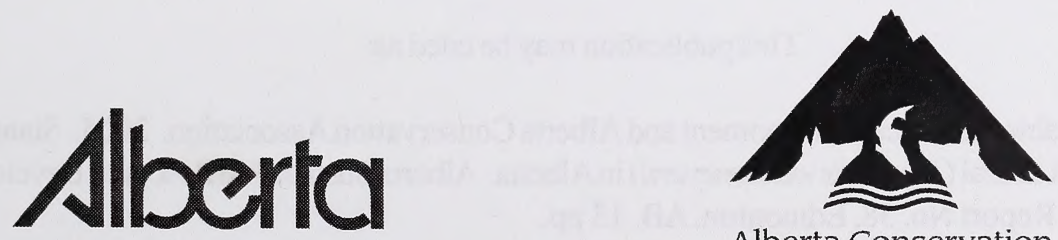

Alberta Conservation Association 
Publication No. T/099

ISBN: 0-7785-4137-1 (Printed Edition)

ISBN: 0-7785-4138-X (On-line Edition)

ISSN: 1206-4912 (Printed Edition)

ISSN: 1499-4682 (On-line Edition)

Series Editors: Sue Peters, Robin Gutsell, Nyree Sharp and Lisa Matthias Illustrations: Brian Huffman

Maps: Jane Bailey

For copies of this report,visit our web site at :

http://www3.gov.ab.ca/srd/fw/speciesatrisk/

and click on "Detailed Status"

$O R$

Contact:

Information Centre - Publications

Alberta Sustainable Resource Development

Main Floor, Great West Life Building

9920 - 108 Street

Edmonton, Alberta, Canada T5K 2M4

Telephone: (780) 422-2079

This publication may be cited as:

Alberta Sustainable Resource Development and Alberta Conservation Association. 2005. Status of the Weidemeyer's Admiral (Limenitis weidemeyerii) in Alberta. Alberta Sustainable Resource Development, Wildlife Status Report No. 58, Edmonton, AB. 13 pp. 


\section{PREFACE}

Every five years, the Fish and Wildlife Division of Alberta Sustainable Resource Development reviews the general status of wildlife species in Alberta. These overviews, which have been conducted in 1991 (The Status of Alberta Wildlife), 1996 (The Status of Alberta Wildlife) and 2000 (The General Status of Alberta Wild Species 2000), assign individual species "ranks" that reflect the perceived level of risk to populations that occur in the province. Such designations are determined from extensive consultations with professional and amateur biologists, and from a variety of readily available sources of population data. A key objective of these reviews is to identify species that may be considered for more detailed status determinations.

The Alberta Wildlife Status Report Series is an extension of the general status exercise, and provides comprehensive current summaries of the biological status of selected wildlife species in Alberta. Priority is given to species that are At Risk or May Be At Risk in the province, that are of uncertain status (Undetermined), or that are considered to be at risk at a national level by the Committee on the Status of Endangered Wildlife in Canada (COSEWIC).

Reports in this series are published and distributed by the Alberta Conservation Association and the Fish and Wildlife Division of Alberta Sustainable Resource Development. They are intended to provide detailed and up-to-date information that will be useful to resource professionals for managing populations of species and their habitats in the province. The reports are also designed to provide current information that will assist Alberta's Endangered Species Conservation Committee in identifying species that may be formally designated as Endangered or Threatened under Alberta's Wildlife Act. To achieve these goals, the reports have been authored and/or reviewed by individuals with unique local expertise in the biology and management of each species. 


\section{EXECUTIVE SUMMARY}

The Weidemeyer's admiral is a butterfly that is limited in distribution within Canada to two groups of known populations along the lower Milk River of southern Alberta. Within this small geographic area it is narrowly confined to naturally fragmented areas of taller shrubs and deciduous trees for breeding purposes. The total known population in Alberta is estimated to be a maximum of 3000 adults. Population levels certainly fluctuate in response to natural processes such as drought and extreme weather events. Not all potential habitat for the species has been examined for presence of the species. The total area of occupied habitat within the currently known range is probably less than one square kilometre.

Land use intensity in the Alberta range of the species has remained fairly stable over the past 30 years and is not known to have significant adverse consequences for these butterflies. However, major development projects or increased livestock grazing intensity could increase the level of risk to the continued presence of the species. The combination of highly circumscribed range and small area of known breeding habitat render this a species worthy of continued conservation attention, despite the lack of known imminent threats to its continued survival. Riparian and range management practices that maintain shrubs used as larval food plants in the landscape will continue to benefit the species. Raising landowner and land manager awareness, along with field surveys to better define occupied habitat patches, are appropriate management responses at this time. 


\section{ACKNOWLEDGEMENTS}

The following individuals kindly contributed information on Weidemeyer's admiral: I. Gardiner(Calgary), S. Kohler (Montana), Dr. E. Pike (Calgary), Dr. R. Royer (Minot State University, North Dakota), Dr. S. Spomer (University of Nebraska, Lincoln), and T. Stout (Utah). The Alberta Natural Heritage Information Centre shared data from its files. Funding for this report was provided by the Alberta Conservation Association and the Fish and Wildlife Division of Alberta Sustainable Resource Development. Several private landowners graciously allowed access during the field survey in 2004. Thanks to Richard Quinlan (Alberta Sustainable Resource Development) and Lance Engley (Alberta Conservation Association) for making this report possible. Dr. Ted Pike and Steve Kohler (Missoula, Montana) reviewed an early draft of this report.

Preparation of this report was funded by the Alberta Conservation Association and the Fish and Wildlife Division of Alberta Sustainable Resource Development. 
Digitized by the Internet Archive in 2016 


\section{TABLE OF CONTENTS}

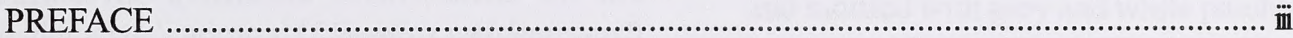

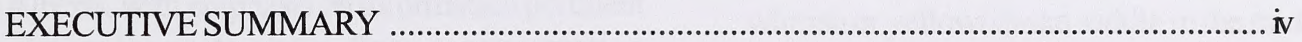

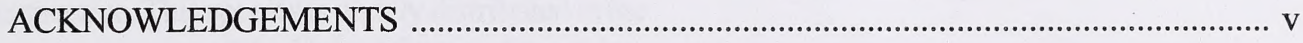

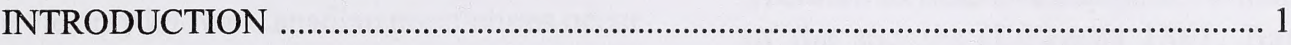

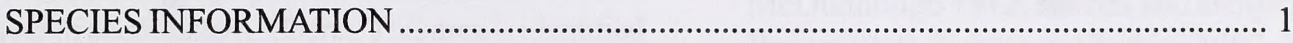

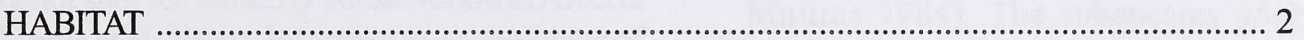

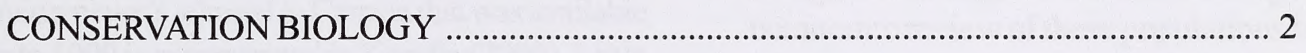

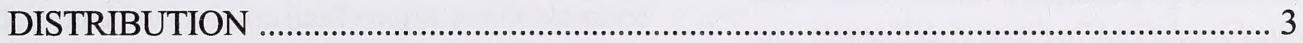

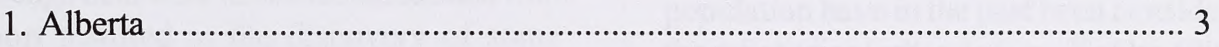

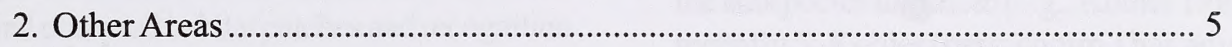

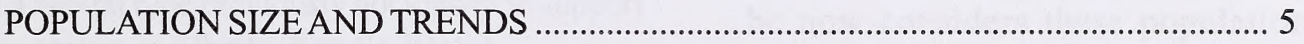

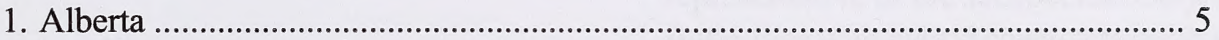

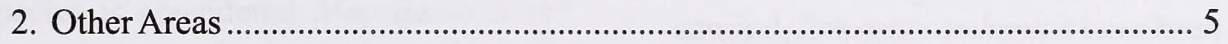

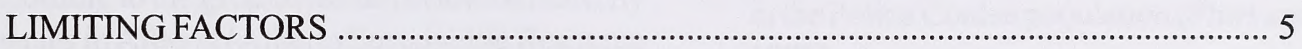

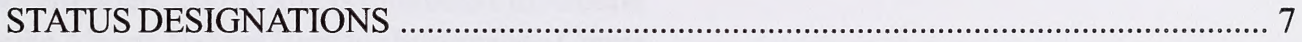

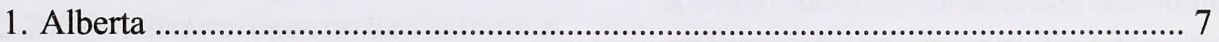

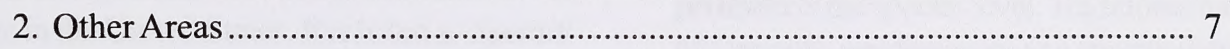

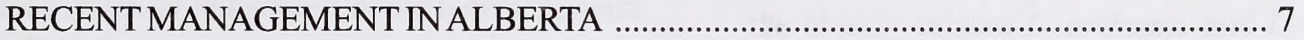

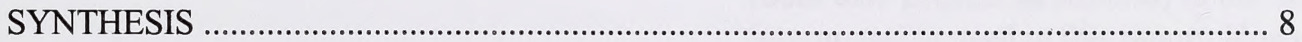

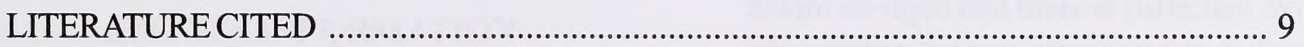

APPENDIX 1 Definitions of selected legal and protective designations. ................................ 12

\section{LIST OF FIGURES}

Figure 1 Distribution of Weidemeyer's admiral in Alberta .................................................. 4

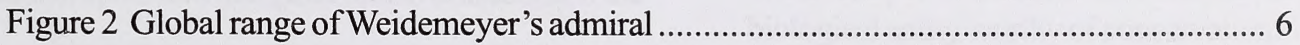





\section{INTRODUCTION}

The purpose of this report is to compile and summarize available information on the Weidemeyer's admiral (Limenitis weidemeyerii) in Alberta, with emphasis on information pertinent to determining its status from a conservation perspective. This species is widely distributed in the western interior of the United States of America, but the only known Canadian populations occur within a small geographic area along the lower Milk River of southeastern Alberta. This area is identified as a hot spot for butterfly conservation in Alberta (Kondla et al. 2000). Information on the status of Weidemeyer's admiral in Canada that was available up to 1999 is summarized in Kondla (2000). Little additional information has become available since then, although field work in 2004 in association with this report resulted in the discovery of some additional occupied habitat patches and recognition of a habitat type previously not known to support this species in Alberta (Kondla 2004a).

This species is considered May Be At Risk* according to the general status review of butterfly species in Alberta (Alberta Sustainable Resource Development 2001), and is ranked S1 in Alberta by the Alberta Natural Heritage Information Centre (ANHIC 2004). It has not been ranked in most of its range in the United States. It is listed as Special Concern under Schedule 1 of the federal Species At Risk Act.

\section{SPECIES INFORMATION}

Weidemeyer's admiral is one of the larger Alberta butterfly species, with a wingspan in the range of $55 \mathrm{~mm}$ to $72 \mathrm{~mm}$. The dorsal wing surface is predominantly black with prominent wide, white bands on both wings. The white bands are repeated on the ventral wing surface and the overall ventral appearance is whitish, with a submarginal band of reddish spots and marginal bluish crescents on the hind wing. Scott (1986a) has described the appearance of the eggs, larvae and pupae. Larvae are olive-green with yellowish-tan areas or greyish and mottled with grey and white patches. Larvae have a red-brown head. The larval body has a whitish or yellowish-tan saddle in the middle and a whitish lateral band.

There are six described subspecies within the range of the species (Edwards 1861, Barnes and McDunnough 1912, Barnes and Benjamin 1924, Brown 1960, Perkins and Perkins 1967, Austin and Mullins 1984). The subspecies oberfoelli is recognized to occur in Canada, although a formal taxonomic review of these populations has never been undertaken. Montana populations from the area immediately south of the Police Coulee, Alberta population have in the past been considered to be the subspecies latifascia (e.g., Kohler 1980). More recently S. Kohler (pers. comm.) has advised that he now considers these populations to be representative of the subspecies oberfoelli also. Butterflies with hybrid characters (with the white admiral, Limenitis arthemis) have been reported in the Police Coulee population (Pinel and Kondla 1985).

Kondla (2000) has summarized taxonomic matters pertinent at the species level. Traditional recognition of Limenitis weidemeyerii as a species distinct from the closely related $L$. arthemis and $L$. lorquini (both also present in Alberta) is the taxonomic interpretation used in this report. However, it is acknowledged that there is sufficient evidence of gene exchange among these taxa (e.g., Porter 1990) that it would be defensible to treat both the named $L$. weidemeyerii subspecies and the named $L$. lorquini subspecies as subspecies of $L$. arthemis. This choice is a matter of taxonomic judgement, differing species concepts and the weight that one places on various taxonomic characters. The taxonomic options do not change the status of Weidemeyer's admiral in Alberta as being a biological entity worthy of conservation.

\footnotetext{
* See Appendix 1 for definitions of selected status designations.
} 


\section{HABITAT}

This species is generally reported to use woody riparian habitats in its range. Such habitats are also used in Alberta. Pike (1987) mentioned cottonwoods (Populus spp.), saskatoon (Amelanchier alnifolia), western clematis (Clematis ligusticifolia) and thorny buffaloberry (Shepherdia argentea) in occupied habitat. He did not find admirals in large stands of willow (Salix sp.), although Porter (1989) reported some use of willow thicket edges in New Mexico. Royer (2003) refers to this admiral as being "thoroughly a badlands butterfly" that inhabits woodland breaks in North Dakota. In the Sweetgrass Hills of Montana, immediately adjacent to Canadian populations, the admiral uses higher elevation treed riparian areas along ephemeral streams, as well as smaller shrub patches at lower elevations (N. Kondla and S. Kohler, unpubl. data).

Before 2004, the habitat of Weidemeyer's admiral in Alberta was also thought to include only riparian areas with deciduous trees. The known range of occupied habitats was expanded through field work in 2004 to include small patches of choke cherry (Prunus virginiana) and saskatoon in ravines and coulees some distance from the nearest treed riparian habitats. The critical habitat attribute for this species in Alberta is the presence of deciduous trees or taller shrubs as food plants for the caterpillars.

Three primary and distinct habitat types are now known to be used in Alberta: riparian forest and shrubbery along the Milk River valley bottom, pockets of trees and shrubs along a few tributary coulees and ravines, and small patches of choke cherry/saskatoon shrubs in some coulees and ravines. In 2004, male admirals were observed engaging in perching/patrolling mate-locating behaviour at extremely small shrub patches that can be measured in square feet. Such small patches by themselves are insufficient to sustain a population of butterflies, but coulees or ravines that have multiple small shrub patches do qualify as admiral habitat. The location of shrub patches in sheltered landscape positions also provides protection from strong prairie winds and thus facilitates mate-locating behaviour.
Habitat patches within the known range of the species in Alberta appear to be stable. Only very large-scale fires could plausibly result in a significant reduction in habitat supply. Visually suitable habitat, as defined by the presence of taller shrubs, is present outside of the known provincial range of Weidemeyer's admiral. These geographic areas, both east and west of the known range, have never been subjected to field inventory for this species. Not all potential habitat patches within the known Alberta range have been examined, so it is not known what percentage of visually suitable habitat is actually occupied by the species.

\section{CONSERVATION BIOLOGY}

This species has a typical lepidopteran life cycle of egg, larva (caterpillar), pupa and adult. Females deposit eggs near the dorsal tip of deciduous tree and shrub leaves. Outside of Alberta these plants are reported to be poplars, willow, saskatoon and choke cherry (Scott 1986b, 1992; Royer 2003). The only confirmed oviposition (egg-laying) substrate in Alberta is saskatoon (Pike 1987), although it is likely that other woody plants are used. The species has a one-year generation time, with the wintering stage being third instar larvae in a hibernaculum. Adults have been observed between 7 June and 22 July in Alberta (Bird et al. 1995).

The behaviour of adults has been described by Scott (1975), Pike (1987), Rosenberg (1989a), and Rosenberg and Renquist (1991). Males use a combination of perching and patrolling mate-locating behaviour. Males are reported to defend territories and engage in aerial contest behaviour. Gravid females spend much of their time moving through the breeding habitat in search of oviposition sites. Adults take nutrients and moisture from tree sap, flowers, carrion and mud. As is typical of most butterfly species, they are not disturbed by human presence, unless it includes rapid movement near the butterfly.

The presence of taller deciduous shrubs or trees is an absolute habitat requirement for the admiral, since only these plants are known to be used as food by 
the caterpillars. Ideal habitat for the species includes the presence of the larval food plant in an area sheltered from strong wind, the presence of flowering plants for adult nectar sources, and damp soil or mud for mineral uptake (Scott 1986a, Pike 1987, Rosenberg 1989b). Habitat fragmentation is not an issue with this species because the habitat is naturally fragmented and the adults easily fly between patches of breeding habitat (N. Kondla, unpubl. data). Rosenberg (1989a) considered the species to be "a strong flier." They use ravines and coulees as flight corridors, and have not yet been seen to fly over open prairie in Alberta. However, it is probable that adults do occasionally fly in open prairie habitat. Rosenberg (1989a) conducted mark-recapture studies at four Colorado locations. Results showed that the mean distance traveled by both sexes during the flight season was 166 metres, but the range of movement distances varied from zero to 2850 metres. These observed movement distances should not be confused with the ability of adults to fly even longer distances.

\section{DISTRIBUTION}

1. Alberta - The first published record for the province was by Gregory (1975), on the basis of a specimen collected by Gamble Geddes in 1883 . Exact collection locations of such ancient specimens, long before the availability of detailed maps and abundant named geographic locations, are unknown. It is likely, based on information in Geddes' publications, that the specimen was collected in extreme southwestern Alberta. Smith and Bird (1977a) reported the first contemporary record of the species from the lower Milk River. Smith and Bird (1977b) subsequently questioned the validity of the Geddes record. The species has not subsequently been found in southwestern Alberta.

Known contemporary locations for the species in Alberta (Figure 1) are confined to an approximate $80-\mathrm{km}$ stretch of the lower Milk River, tributary coulees and the extreme lower Lost River valley (Smith and Bird 1977a\&b; Thormin et al. 1980; Pinel and Kondla 1985; Pike 1987; Kondla 1998,
2000, 2004a; Alberta Natural Heritage Information Centre data). Known locations are grouped into a westerly suite and an easterly suite, without any known linking populations. Current information suggests that these eastern and western assemblages of known locations represent two metapopulations (sets of local populations connected by dispersing individuals). There are three populations in the eastern metapopulation and four populations in the western metapopulation, based on the geographic area within which the species is distributed and the fragmented nature of the breeding habitat within the area. It is probable that there is some movement of adults between the two metapopulations, but there are no data to render this a certainty. Definitive separation distances and the amount of exchange among populations within each metapopulation are unknown.

The full distribution of this species in Alberta is not yet known. Fieldwork to date has largely focused on the areas of the two known metapopulations. Additional survey effort is needed in the apparent distributional gap to determine if it is real. Presence/ absence surveys are also needed to the east and to the west of the currently known distribution.

The distribution of Weidemeyer's admiral in Alberta is entirely within the Mixedgrass and Dry Mixedgrass Natural Subregions of the Grassland Natural Region. However, the species is not a grassland butterfly and is entirely dependent on small patches of atypical habitat within the landscapescale grassland and cropland matrix. The plausible maximum extent of occurrence, based on the species' presently known range, is roughly estimated as $1700 \mathrm{~km}^{2}$. The area of occupancy is a very small subset of the extent of occurrence, in accordance with the highly fragmented and very limited extent of woody vegetation within the known range. Available vegetation mapping is not sufficiently detailed to permit a calculation of the plausible area of occupancy within the known range. However, rough estimation from field and air photo information suggests that it is likely less than a few percent of the extent of occurrence. The total area of habitat occupied by larval food plants, in areas where the 


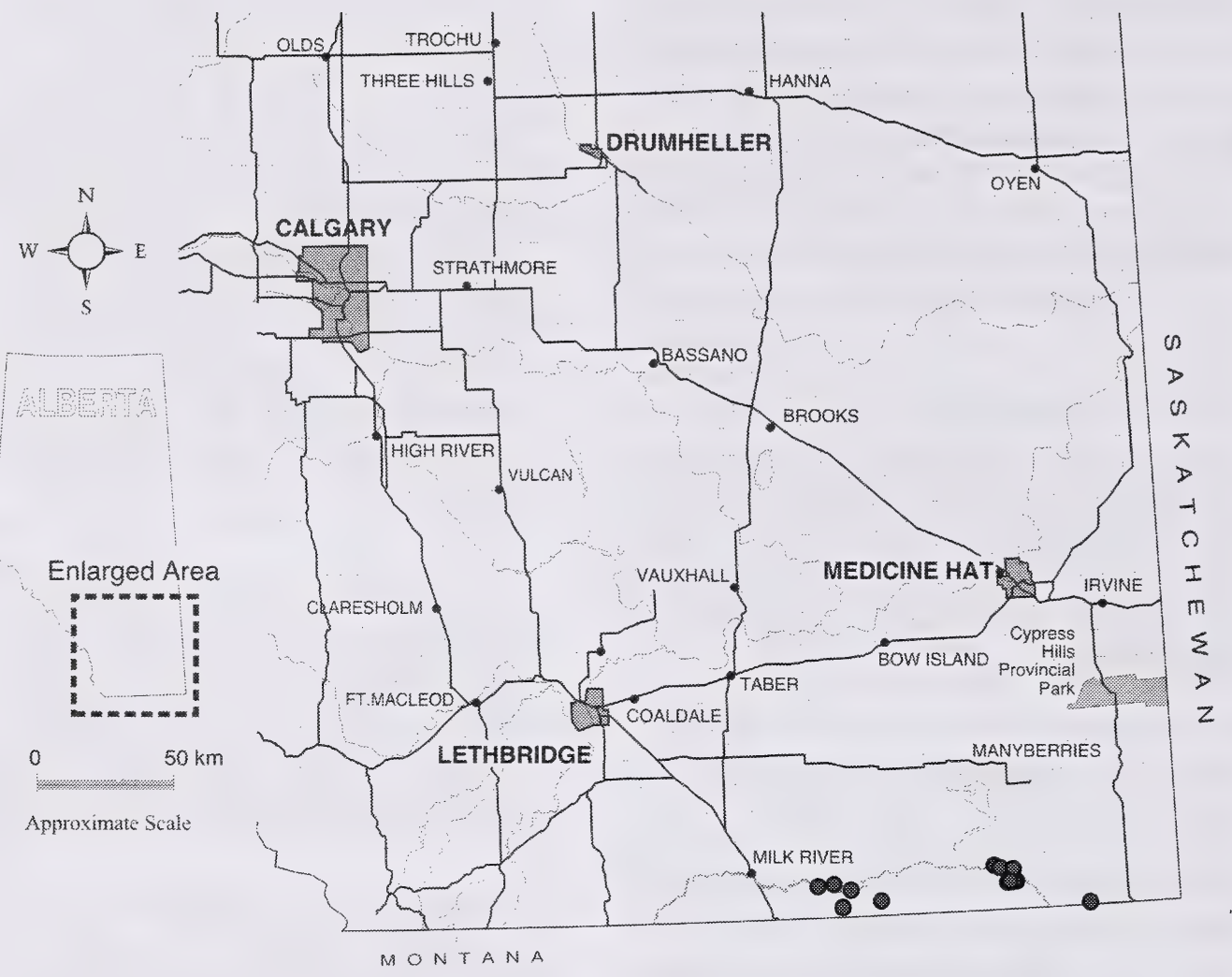

Figure 1. Distribution of Weidemeyer's admiral in Alberta. 
admiral is known to occur, is probably less than one square kilometre.

Habitat suitability modeling (Taylor 2004) likely overestimates the amount of potential Weidemeyer's admiral habitat in Alberta. The habitat model itself is sound in relation to present knowledge of the butterfly, but the minimum size of the mapped vegetation polygons presently available for application of the model are too large relative to the size of the habitat patches used by the butterfly. This problem, in combination with polygons that do not contain the requisite shrub species, results in an overly generous portrayal of potential habitat deployment over the landscape.

2. Other Areas - The Canadian distribution is the same as the Alberta distribution. A record for western Ontario reported by Layberry et al. (1998) is well outside the known range of the species and is likely a mislabelled specimen or a stray transported to Ontario by natural means or human assistance.

The global range of this species is almost all within the United States of America (Figure 2). The species is distributed from extreme southern Alberta southeast to central Nebraska, south to southern Arizona and southwest to east-central California. The subspecies oberfoelli is confined to the northeastern fringe of the global range.

\section{POPULATION SIZE AND TRENDS}

1. Alberta - Kondla (2000) estimated a maximum total adult population in the range of 1800 to 3200 individuals. This was based on extrapolation from estimates provided by Pike (1987) on the number of adults seen per linear kilometre of habitat. It is stressed that the estimate of maximum total adult population size assumed occupancy of habitats that have not been inventoried for admiral presence. However, since adults are now known to use habitat types not included in this prior estimate, the plausible maximum adult population may be larger. This estimate was also based on the assumption that the species is not present outside the currently known
Alberta range. Based on mark-recapture work in Colorado, Rosenberg (1989b) estimated the minimum average population size to be 126 . This can also be used to infer a minimum average total population size of the known Alberta populations. If it is assumed that the Colorado estimate reasonably approximates population size in Alberta, and if one interprets current known locations in Alberta as consisting of 7 populations, then the minimum total Alberta population size, for known populations, could be as little as approximately 900 adults. In Colorado, discrete populations with little interchange of individuals and significant allele frequency differences can be separated by a distance as short as $4 \mathrm{~km}$ (Rosenberg 1989b). In Alberta, we currently don't have enough information to draw definitive boundaries around the populations.

More definitive population estimates cannot be provided without substantial additional fieldwork over multiple years with variable weather conditions. Insect populations are well known for substantial population fluctuations from one year to the next and it is reasonable to believe that Weidemeyer's admiral populations in Alberta will also experience such fluctuations over time because of natural stochastic events. Such population fluctuations could be one order of magnitude in size, such as has been observed in the sooty hairstreak butterfly in Alberta (Kondla 2004b), or even result in population-level extinction, as has been observed in the silvery blue butterfly (Ehrlich et al. 1972). There is insufficient historical information to allow even an estimate of population trends over time for Weidemeyer's admiral.

2. Other Areas - The only empirical information on population size in other areas is for four populations in Colorado (Rosenberg 1989b). The species appears to be perceived as a common butterfly in suitable habitats in the United States.

\section{LIMITING FACTORS}

The primary limiting factor at the landscape scale is the very small area of shrubby and treed habitat that naturally occurs as small patches within the 


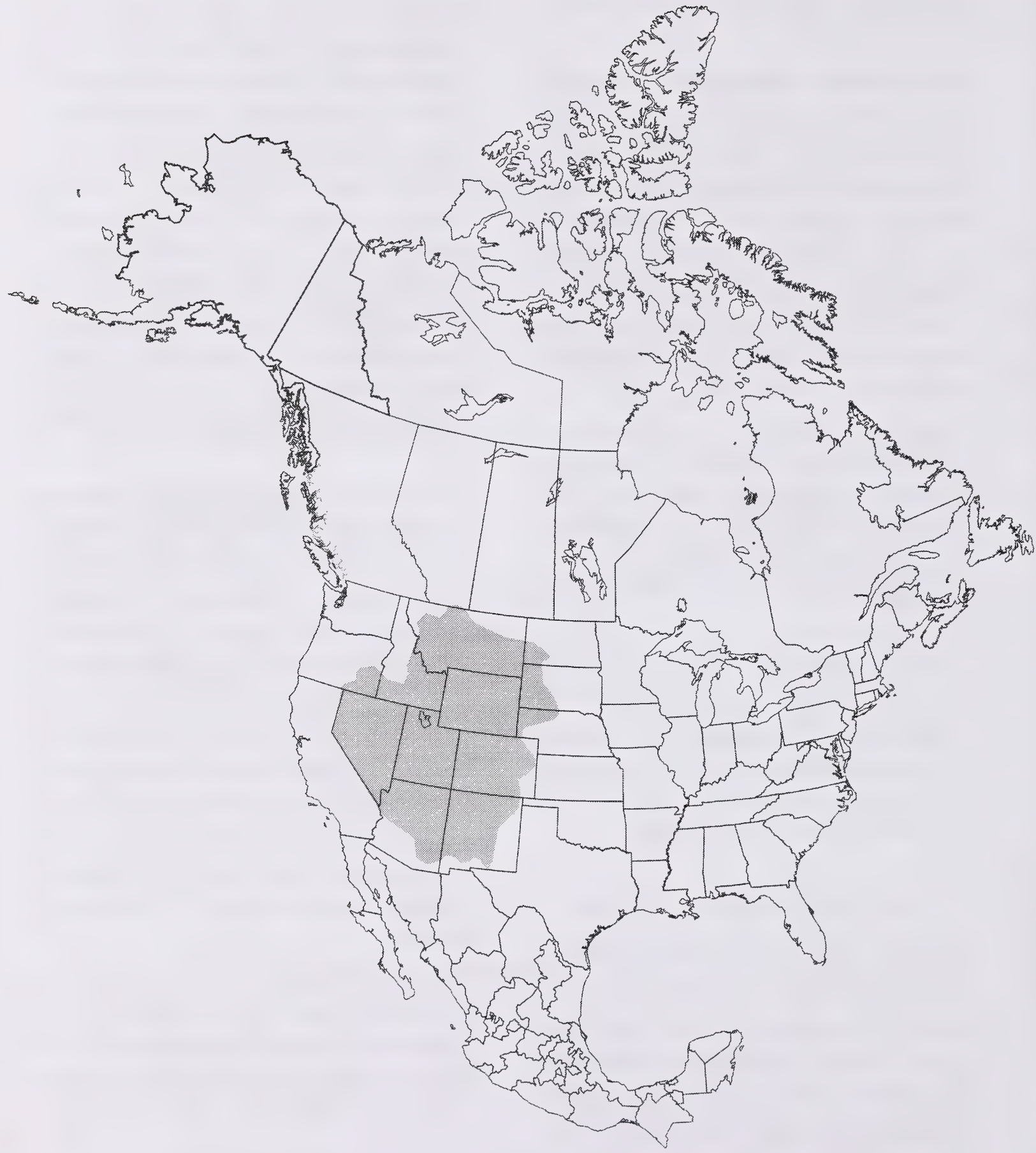

Figure 2. Global range of Weidemeyer's admiral. 
prairie landscape in Alberta. Periodic severe droughts probably have some impact on population levels, but the species has survived such past natural perturbations. Severe multi-year droughts can reduce the quantity and quality of larval food resources as well as nectar resources for adults. Global warming could result in loss of some small habitat patches, but could also expand the land base climatically suitable for use by the species. A wildfire has consumed admiral habitat within recent times along the lower Milk River and could also be a limiting factor for habitat supply in the future.

Besides providing the topographic and edaphic conditions for the admiral larval food plants, ravines and coulees are also used as flight corridors by adults as they move between breeding habitat patches. If the Milk River valley were to be flooded through dam construction (for background information, see http://www3.gov.ab.ca/env/water/reports/ milk_river/, the main valley bottom breeding habitat would be destroyed, although primary breeding habitat patches in the ravines and coulees are at the upper elevations and would probably be less affected by a reservoir on the Milk River than the valley bottom habitat.

Based on extrapolation from other butterflies and insects, other population-level limiting factors include stochastic weather events and predation on early stages. The levels of mortality experienced by butterflies, from natural and human-induced causes, are not of equivalent concern to such mortality levels in birds and mammals because of the inherent capability for short-term population recovery. Insects have substantially higher fecundity than do vertebrate animals. The number of eggs laid by a female Weidemeyer's admiral in the wild is unknown, but captive rearing has resulted in more than 100 eggs being laid by a female (T. Stout, unpubl. data).

Human activities are not known to have had a measurable consequence for the species in Alberta. The breeding habitat is physically unsuitable for cultivation agriculture and construction of buildings. Kondla (2000) provides discussion and a structured risk assessment for livestock grazing, flooding, industrial infrastructure, recreation, fire and specimen collecting. None of these activities, alone or in combination, are thought to present serious imminent threats under the present land use regime. This situation could easily change with the probable intensification of land use over the long term, considering increasing human pressures on the landscape. A small amount of habitat has been lost to stock watering structures, and some mortality probably occurs as a result of incidental ingestion of early stages by livestock and native ungulates, as well as the dislodging of larvae and subsequent trampling.

\section{STATUS DESIGNATIONS*}

1. Alberta - Weidemeyer's admiral is listed as May Be At Risk in The General Status of Alberta Wild Species 2000 (Alberta Sustainable Resource Development 2001). It is ranked as S1 by the Alberta Natural Heritage Information Centre (ANHIC 2004).

2. Other areas - The species is legally listed as Special Concern in Schedule 1 of the federal Species At Risk Act. According to NatureServe (2005), the global status of the species is G5. In states that border Canada, the species' state status is S5 (Montana) and SNR (North Dakota). The state status in 11 of the 15 states within the global range of the species is not ranked or is undetermined.

It is also important to consider that the global population is not one gene pool (e.g., Rosenberg $1989 \mathrm{~b}$ ), and not one taxonomic entity. The subspecies that occurs in Alberta (oberfoelli subspecies) is limited to approximately $20 \%$ of the global range.

\section{RECENT MANAGEMENT IN ALBERTA}

There has been no management activity targeting this species in Alberta. Normal range management

\footnotetext{
* See Appendix 1 for definitions of selected status designations.
} 
practices that are consistent with long-term productivity of grasslands appear to incidentally constrain livestock use to levels that allow the Weidemeyer's admiral to persist. The species has no current economic uses; however, in combination with other noteworthy butterfly species in the same area, does have potential use as a component of ecotourism development.

\section{SYNTHESIS}

The Weidemeyer's admiral (oberfoelli subspecies) is known to occur in an extremely small area of southern Alberta. These are the only known Canadian populations. Globally, the species is restricted to mid-western North America. The butterflies are totally dependent on the highly fragmented stands of taller shrubs and deciduous trees that occur in a prairie landscape. Surveys have not yet been carried out for all potential habitat patches in Alberta. Available information suggests that a total population of less than 3000 adult individuals is plausible. Actual population levels and full distribution in Alberta may turn out to be otherwise when the necessary field inventory has been completed over a period of years. Population estimates will remain approximate because it is not unusual for insects to experience substantial and rapid natural population fluctuations.

There are no known serious and imminent threats at this time, but the small known total population confined to a small land base is vulnerable to major stochastic natural processes and substantial changes in the land use regime. These butterflies are therefore a legitimate subject of conservation attention in Alberta. Current management on public lands appears to prevent excessive use of admiral breeding habitat by livestock. The situation is less clear on private lands, and landowner cooperation will be needed to accommodate future generations of these admirals on private land.

Elaborate programs do not appear to be needed to safeguard the species in Alberta for the foreseeable future, provided that land use intensity does not significantly change. Management programs and projects that attend to shrubby and wooded riparian habitats will most likely also benefit the admiral. The primary initiative over the next several years should be to conduct presence/absence surveys in a larger geographic area to determine if the species is as distribution-limited as present information indicates. Mark-recapture work is needed to develop better estimates of population sizes. 


\section{LITERATURE CITED}

Alberta Sustainable Resource Development. 2001. The general status of Alberta wild species 2000. Alberta Sustainable Resource Development, Fish and Wildlife Service, Edmonton, AB. 46 pp.

ANHIC. 2004. Alberta Natural Heritage Information Centre Butterfly Tracking List. URL: http://www.cd.gov.ab.ca/preserving/ parks/anhic/butterflies tracking.asp. [Last Updated September 2004].

Austin, GT., and D. Mullins. 1984. Anew Limenitis weidemeyerii W.H. Edwards from southeastern Arizona (Nymphalidae). Journal of Research on the Lepidoptera 22:225-228.

Barnes, W., and F.H. Benjamin. 1924. Basilarchia weidemeyerii race nevadae nov. Contributions to the Natural History of the Lepidoptera of North America 5:99.

Barnes, W., and J. McDunnough. 1912. Basilarchia weidemeyerii angustifascia, a new geographical race. Canadian Entomologist 44:163

Bird, C.D., G.J. Hilchie, N.G. Kondla, E.M. Pike and F.A. Sperling. 1995. Alberta butterflies. Provincial Museum of Alberta, Edmonton, Alberta. 349 pp.

Brown, F.M. 1960. A badlands subspecies of Limenitis weidmeyerii. American Museum Novitates 2018:1-6.

COSEWIC. 2005. Database. Committee on the Status of Endangered Wildlife in Canada. URL: http://www.cosewic.gc.ca [Last Updated: September 2005]

Edwards, W.H. 1861. Descriptions of certain species of diurnal lepidoptera, found within the limits of the United States and of British
America. Proceedings of the Academy of Natural Sciences of Philadelphia 13:160164.

Ehrlich, P.R., D.E. Breedlove, P.F. Brussard, M.A. Sharp. 1972. Weather and the regulation of subalpine populations. Ecology 53:24347.

Gregory, W.W. 1975. Checklist of the butterflies and skippers of Canada. Lyman Entomological Museum, Memoir No. 3. Ste.-Anne-de-Bellevue, Quebec. 44 pp.

Kohler, S. 1980. Checklist of Montana butterflies (Rhopalocera). Journal of the Lepidopterists' Society 34:1-19.

Kondla, N.G. 1998. Alberta butterflies of conservation interest: an overview. Alberta Natural Heritage Information Centre. 15 pp plus maps.

Kondla, N.G. 2000. Status report on the Weidemeyer's Admiral butterfly (Limenitis weidemeyerii W.H. Edwards) in Canada. Committee on the Status of Endangered Wildlife in Canada. Ottawa. 14 pp.

Kondla, N.G. 2004a. Weidemeyer's admiral field survey, 2004. File report prepared for Alberta Conservation Association and Alberta Fish and Wildlife. 6 pp.

Kondla, N.G. 2004b. Waterton Lakes National Park Sooty Hairstreak survey, 2004. Report for Parks Canada. 24 pp.

Kondla, N.G., C.S. Guppy and J.H. Shepard. 2000. Butterflies of conservation interest in Alberta, British Columbia, and Yukon. Pp. 95-100 in Darling, L.M. (ed.). Proceedings of a Conference on the Biology and Management of Species and Habitats at Risk. Volume 1. BC Ministry of Environment, Lands and Parks and University College of the Caribou. $490 \mathrm{pp}$ 
Layberry, R.A., P.W. Hall and J.D. Lafontaine. 1998. The butterflies of Canada. University of Toronto Press. Toronto, Ontario. 280 pp.

National Research Council. 1995. Science and the Endangered Species Act. National Academy Press, Washington, DC. 271 pp.

NatureServe 2005. NatureServe Explorer: an online encyclopedia of life [web application]. Version 4.6. Arlington, Virginia, USA: NatureServe. URL: $\underline{\text { http:// }}$ www.natureserve.org/explorer/. [Last updated: October 2005]

Perkins, S.F., and E.M. Perkins. 1967. Revision of the Limenitis weidemeyerii complex, with description of a new subspecies. Journal of the Lepitdopterists' Society 21:213-234.

Pike, E.M. 1987. Limenitis weidemeyerii or Weidemeyer's admiral in Canada. Prepared for World Wildlife Fund. 10 pp.

Pinel, H.W., and N.G. Kondla. 1985. Skippers and butterflies of the Police Coulee area, Alberta. Blue Jay 43:213-223.

Porter, A.H. 1989. Genetic evidence for reproductive isolation between hybridizing Limenitis butterflies (Lepidoptera: Nymphalidae) in southwestern New Mexico. American Midland Naturalist 122:275-280.

Porter, A.H. 1990. Testing nominal species boundaries using gene flow statistics: the taxonomy of two hybridizing admiral butterflies (Limenitis:Nymphalidae). Systematic Zoology 39:131-147.

Rosenberg, R.H. 1989a. Behaviour of the territorial species Limenitis weidemeyerii (Nymphalidae) within temporary feeding areas. Journal of the Lepidopterists' Society 43:102-107.
Rosenberg, R.H. 1989b. Genetic differentiation among populations of Weidemeyer's admiral butterfly. Canadian Journal of Zoology 67:2294-2300.

Rosenberg, R.H., and M. Enquist. 1991. Contest behaviour in Weidemeyer's admiral butterfly Limenitis weidemeyerii (Nymphalidae): the effect of size and residency. Animal Behaviour 42:805-812.

Royer, R.A. 2003. Butterflies of North Dakota. Minot State University Science Monograph Number 2. Minot, North Dakota. 192 pp.

Scott, J.A. 1975. Mate-locating behaviour of western North American butterflies. Journal of Research on the Lepidoptera 14:1-40.

Scott, J.A. 1986a. The butterflies of North America: a natural history and field guide. Stanford University Press. Stanford University. 583 $\mathrm{pp}$.

Scott, J.A. 1986b. Larval hostplant records for butterflies and skippers (mainly from western U.S.), with notes on their natural history. Papilio (New Series) 4:1-37.

Scott, J.A. 1992. Hostplant records for butterflies and skippers (mostly from Colorado) 1959-1991, with new life histories and notes on oviposition, immatures, and ecology. Papilio (New Series) 6:1-171.

Smith, W.W., and C.D. Bird. 1977a. Some butterflies and skippers from the Milk RiverLost River area of southeastern Alberta. Blue Jay 35:15-18.

Smith, W.W., and C.D. Bird. 1977b. Errata: some butterflies and skippers from the Milk RiverLost River area of southeastern Alberta. Blue Jay 35:77.

Taylor, B.N. 2004. Weidemeyer's Admiral (Limenitis weidemeyerii). Pp. 131-135 in 
Downey, B.A., B.L. Downey, R.W. Quinlan, O. Castelli, V.J. Remesz and P.F. Jones (eds). 2004. MULTISAR: the Milk River basin habitat suitability models for selected wildlife management species. Alberta Sustainable Resource Management, Fish and Wildlife Division, Alberta Species at Risk Report No. 86, Edmonton, $\mathrm{AB}$.
Thormin, T.W., N.G. Kondla and C.D. Bird. 1980. Further records of skippers and butterflies from the Milk River-Lost River area of southeastern Alberta. Blue Jay 38:5-10. 
Appendix 1. Definitions of selected legal and protective designations.

A. The General Status of Alberta Wild Species 2000 (after Alberta Sustainable Resource Development 2001)

\begin{tabular}{|c|c|c|}
\hline 2000 Rank & 1996 Rank & Definitions \\
\hline At Risk & Red & $\begin{array}{l}\text { Any species known to be At Risk after formal detailed status } \\
\text { assessment and designation as Endangered or Threatened in } \\
\text { Alberta. }\end{array}$ \\
\hline May Be At Risk & Blue & $\begin{array}{l}\text { Any species that may be at risk of extinction or extirpation, and is } \\
\text { therefore a candidate for detailed risk assessment. }\end{array}$ \\
\hline Sensitive & Yellow & $\begin{array}{l}\text { Any species that is not at risk of extinction or extirpation but may } \\
\text { require special attention or protection to prevent it from becoming } \\
\text { at risk. }\end{array}$ \\
\hline Secure & Green & Any species that is not At Risk, May Be At Risk or Sensitive. \\
\hline Undetermined & $\begin{array}{l}\text { Status } \\
\text { Undetermined }\end{array}$ & $\begin{array}{l}\text { Any species for which insufficient information, knowledge or data } \\
\text { is available to reliably evaluate its general status. }\end{array}$ \\
\hline Not Assessed & $\mathrm{n} / \mathrm{a}$ & $\begin{array}{l}\text { Any species known or believed to be present but which has not yet } \\
\text { been evaluated. }\end{array}$ \\
\hline Exotic/Alien & $\mathrm{n} / \mathrm{a}$ & $\begin{array}{l}\text { Any species that has been introduced as a result of human } \\
\text { activities. }\end{array}$ \\
\hline Extirpated/Extinct & $\mathrm{n} / \mathrm{a}$ & $\begin{array}{l}\text { Any species no longer thought to be present in Alberta } \\
\text { (Extirpated) or no longer believed to be present anywhere in the } \\
\text { world (Extinct). }\end{array}$ \\
\hline Accidental/Vagrant & $\mathrm{n} / \mathrm{a}$ & $\begin{array}{l}\text { Any species occurring infrequently and unpredictably in Alberta, } \\
\text { i.e., outside its usual range. }\end{array}$ \\
\hline
\end{tabular}

\section{B. Alberta Wildlife Act/Regulation}

Species designated as Endangered under Alberta's Wildlife Act include those listed as Endangered or Threatened in the Wildlife Regulation.

\begin{tabular}{|l|l|}
\hline Endangered & A species facing imminent extirpation or extinction. \\
\hline Threatened & A species that is likely to become endangered if limiting factors are not reversed. \\
\hline
\end{tabular}

C. Committee on the Status of Endangered Wildlife in Canada (after COSEWIC 2005)

\begin{tabular}{|l|l|}
\hline Extinct & A species that no longer exists. \\
\hline Extirpated & A species that no longer exists in the wild in Canada, but occurs elsewhere. \\
\hline Endangered & A species facing imminent extirpation or extinction. \\
\hline Threatened & A species that is likely to become endangered if limiting factors are not reversed. \\
\hline Special Concern & $\begin{array}{l}\text { A species that may become threatened or endangered because of a combination } \\
\text { of biological characteristics and identified threats. }\end{array}$ \\
\hline Not at Risk & A species that has been evaluated and found to be not at risk given current circumstances. \\
\hline Data Deficient & $\begin{array}{l}\text { A species for which there is inadequate information to make a direct, or } \\
\text { indirect, assessment of its risk of extinction. }\end{array}$ \\
\hline
\end{tabular}


Appendix 1 continued.

D. Heritage Status Ranks: Global (G), National (N), Sub-National (S) (after Alberta Natural Heritage Information Centre 2004, NatureServe 2005)

\begin{tabular}{|l|l|}
\hline G1/N1/S1 & $\begin{array}{l}5 \text { or fewer occurrences or only a few remaining individuals. May be especially } \\
\text { vulnerable to extirpation because of some factor of its biology. }\end{array}$ \\
\hline G2/N2/S2 & $\begin{array}{l}6 \text { to } 20 \text { or fewer occurrences or with many individuals in fewer locations. May be } \\
\text { especially vulnerable to extirpation because of some factor of its biology. }\end{array}$ \\
\hline G3/N3/S3 & $\begin{array}{l}21 \text { to } 100 \text { occurrences, may be rare and local throughout its range, or in a restricted } \\
\text { range (may be abundant in some locations). May be susceptible to extirpation } \\
\text { because of large-scale disturbances. }\end{array}$ \\
\hline G4/N4/S4 & Typically > 100 occurrences. Apparently secure. \\
\hline G5/N5/S5 & Typically > 100 occurrences. Demonstrably secure. \\
\hline GX/NX/SX & Believed to be extinct or extirpated, historical records only. \\
\hline GH/NH/SH & Historically known, may be relocated in the future. \\
\hline GNR/NNR/SNR & Unranked-conservation status not yet assessed. \\
\hline
\end{tabular}

E. United States Endangered Species Act (after National Research Council 1995)

\begin{tabular}{|l|l|}
\hline Endangered & $\begin{array}{l}\text { Any species which is in danger of extinction throughout all or a significant portion of } \\
\text { its range. }\end{array}$ \\
\hline Threatened & $\begin{array}{l}\text { Any species which is likely to become an endangered species within the foreseeable } \\
\text { future throughout all or a significant portion of its range. }\end{array}$ \\
\hline
\end{tabular}




\section{List of Titles in This Series \\ (as of December 2005)}

No. 1 Status of the Piping Plover (Charadrius melodus) in Alberta, by David R. C. Prescott. 19 pp. (1997)

No. 2 Status of the Wolverine (Gulo gulo) in Alberta, by Stephen Petersen. 17 pp. (1997)

No. 3 Status of the Northern Long-eared Bat (Myotis septentrionalis) in Alberta, by M. Carolina Caceres and M. J. Pybus. 19 pp. (1997)

No. 4 Status of the Ord's Kangaroo Rat (Dipodomys ordii) in Alberta, by David L. Gummer. 16 pp. (1997)

No. 5 Status of the Eastern Short-horned Lizard (Phrynosoma douglassii brevirostre) in Alberta, by Janice D. James, Anthony P. Russell and G. Lawrence Powell. 20 pp. (1997)

No. 5 Update 2004. Status of the Short-horned Lizard (Phrynosoma hernandesi) in Alberta. Alberta Sustainable Resource Development. 27 pp. (2004)

No. 6 Status of the Prairie Rattlesnake (Crotalus viridis viridis) in Alberta, by Sheri M. Watson and Anthony P. Russell. 26 pp. (1997)

No.7 Status of the Swift Fox (Vulpes velox) in Alberta, by Susan E. Cotterill. 17 pp. (1997)

No. 8 Status of the Peregrine Falcon (Falco peregrinus anatum) in Alberta, by Petra Rowell and David P. Stepnisky. 23 pp. (1997)

No. 9 Status of the Northern Leopard Frog (Rana pipiens) in Alberta, by Greg Wagner. 46 pp. (1997)

No. 9 Update 2003. Status of the Northern Leopard Frog (Rana pipiens) in Alberta. Alberta Sustainable Resource Development. 61 pp. (2003)

No. 10 Status of the Sprague's Pipit (Anthus spragueii) in Alberta, by David R. C. Prescott. 14 pp. (1997)

No. 11 Status of the Burrowing Owl (Speotyto cunicularia hypugaea) in Alberta, by Troy I. Wellicome. 21 pp. (1997)

No. 11 Update 2005. Status of the Burrowing Owl (Athene cunicularia) in Alberta. Alberta Sustainable Resource Development and Alberta Conservation Association. 28 pp. (2005)

No. 12 Status of the Canadian Toad (Bufo hemiophrys) in Alberta, by Ian M. Hamilton, Joann L. Skilnick, Howard Troughton, Anthony P. Russell, and G. Lawrence Powell. 30 pp. (1998)

No. 13 Status of the Sage Grouse (Centrocercus urophasianus urophasianus) in Alberta, by Cameron L. Aldridge. 23 pp. (1998)

No. 14 Status of the Great Plains Toad (Bufo cognatus) in Alberta, by Janice D. James. 26 pp. (1998)

No. 15 Status of the Plains Hognose Snake (Heterodon nasicus nasicus) in Alberta, by Jonathan Wright and Andrew Didiuk. 26 pp. (1998)

No. 16 Status of the Long-billed Curlew (Numenius americanus) in Alberta, by Dorothy P. Hill. 20 pp. (1998)

No. 17 Status of the Columbia Spotted Frog (Rana luteiventris) in Alberta, by Janice D. James. 21 pp. (1998) 
No. 18 Status of the Ferruginous Hawk (Buteo regalis) in Alberta, by Josef K. Schmutz. 18 pp. (1999)

No. 19 Status of the Red-tailed Chipmunk (Tamias ruficaudus) in Alberta, by Ron Bennett. 15 pp. (1999)

No. 20 Status of the Northern Pygmy Owl (Glaucidium gnoma californicum) in Alberta, by Kevin C. Hannah. 20 pp. (1999)

No. 21 Status of the Western Blue Flag (Iris missouriensis) in Alberta, by Joyce Gould. 22 pp. (1999)

No. 21 Update 2005. Status of the Western Blue Flag (Iris missouriensis) in Alberta. Alberta Sustainable Resource Development and Alberta Conservation Association. 29 pp. (2005)

No. 22 Status of the Long-toed Salamander (Ambystoma macrodactylum) in Alberta, by Karen L. Graham and G. Lawrence Powell. 19 pp. (1999)

No. 23 Status of the Black-throated Green Warbler (Dendroica virens) in Alberta, by Michael R. Norton. 24 pp. (1999)

No. 24 Status of the Loggerhead Shrike (Lanius ludovicianus) in Alberta, by David R. C. Prescott and Ronald R. Bjorge. 28 pp. (1999)

No. 25 Status of the Plains Spadefoot (Spea bombifrons) in Alberta, by Richard D. Lauzon. 17 pp. (1999)

No. 26 Status of the Trumpeter Swan (Cygnus buccinator) in Alberta, by M. Lynne James. 21 pp. (2000)

No. 27 Status of the Pygmy Whitefish (Prosopium coulteri) in Alberta, by William C. Mackay. 16 pp. (2000)

No. 28 Status of the Short-eared Owl (Asio flammeus) in Alberta, by Kort M. Clayton. 15 pp. (2000)

No. 29 Status of the Willow Flycatcher (Empidonax traillii) in Alberta, by Bryan Kulba and W. Bruce McGillivray. 15 pp. (2001)

No. 30 Status of the Woodland Caribou (Rangifer tarandus caribou) in Alberta, by Elston Dzus. 47 pp. (2001)

No. 31 Status of the Western Spiderwort (Tradescantia occidentalis) in Alberta, by Bonnie Smith. 12 pp. (2001)

No. 32 Status of the Bay-breasted Warbler (Dendroica castanea) in Alberta, by Michael Norton. 21 pp. (2001)

No. 33 Status of the Cape May Warbler (Dendroica tigrina) in Alberta, by Michael Norton. 20 pp. (2001)

No. 34 Status of the Whooping Crane (Grus americana) in Alberta, by Jennifer L. White. 21 pp. (2001)

No. 35 Status of Soapweed (Yucca glauca) in Alberta, by Donna Hurlburt. 18 pp. (2001)

No. 36 Status of the Harlequin Duck (Histrionicus histrionicus) in Alberta, by Beth MacCallum. 38 pp. (2001)

No. 37 Status of the Grizzly Bear (Ursus arctos) in Alberta, by John L. Kansas. 43 pp. (2002)

No. 38 Status of the Wood Bison (Bison bison athabascae) in Alberta, by Jonathan A. Mitchell and C. Cormack Gates. 32 pp. (2002)

No. 39 Status of the Bull Trout (Salvelinus confluentus) in Alberta, by John R. Post and Fiona D. Johnston. 40 pp. (2002) 
No. 40 Status of the Banff Springs Snail (Physella johnsoni) in Alberta, by Dwayne A.W. Lepitzki. 29 pp. (2002)

No. 41 Status of the Shortjaw Cisco (Coregonus zenithicus) in Alberta, by Mark Steinhilber. 23 pp. (2002)

No. 42 Status of the Prairie Falcon (Falco mexicanus) in Alberta, by Dale Paton. 28 pp. (2002)

No. 43 Status of the American Badger (Taxidea taxus) in Alberta, by Dave Scobie. 17 pp. (2002)

No. 44 Status of the Yucca Moth (Tegeticula yuccasella) in Alberta. Alberta Sustainable Resource Development. 21 pp. (2002)

No. 45 Status of the White-winged Scoter (Melanitta fusca deglandi) in Alberta. Alberta Sustainable Resource Development. 15 pp. (2002)

No. 46 Status of the Lake Sturgeon (Acipenser fulvescens) in Alberta. Alberta Sustainable Resource Development. 30 pp. (2002)

No.47 Status of the Western Silvery Minnow (Hybognathus argyritis) in Alberta. Alberta Sustainable Resource Development. 24 pp. (2003)

No. 48 Status of the Small-flowered Sand Verbena (Tripterocalyx micranthus) in Alberta. Alberta Sustainable Resource Development. 24 pp. (2003)

No. 49 Status of the Brown Creeper (Certhia americana) in Alberta. Alberta Sustainable Resource Development. $30 \mathrm{pp}$. (2003)

No. 50 Status of the Mountain Plover (Charadrius montanus) in Alberta. Alberta Sustainable Resource Development. 25 pp. (2003)

No. 51 Status of the St. Mary Shorthead Sculpin (provisionally Cottus bairdi punctulatus) in Alberta. Alberta Sustainable Resource Development. 24 pp. (2003)

No. 52 Status of the Stonecat (Noturus flavus) in Alberta. Alberta Sustainable Resource Development. 22 pp. (2003)

No. 53 Status of the Sage Thrasher (Oreoscoptes montanus) in Alberta. Alberta Sustainable Resource Development. 23 pp. (2004)

No. 54 Status of the Tiny Cryptanthe (Cryptantha minima) in Alberta. Alberta Sustainable Resource Development. 39 pp. (2004)

No. 55 Status of the Slender Mouse-ear-cress (Halimolobos virgata) in Alberta. Alberta Sustainable Resource Development. 27 pp. (2005)

No. 56 Status of the Barred Owl (Strix varia) in Alberta. Alberta Sustainable Resource Development. 15 pp. (2005)

No. 57 Status of the Arctic Grayling (Thymallus arcticus) in Alberta. Alberta Sustainable Resource Development. 41 pp. (2005)

No. 58 Status of the Weidemeyer's Admiral (Limenitis weidemeyerii) in Alberta. Alberta Sustainable Resource Development and Alberta Conservation Association. 13 pp. (2005) 

LIBRARY AND ARCHIVES CANADA

Bibliotheque et Archives Canada

||

33286534697053 